\title{
A Theoretical Framework to Support Internationalization of SMEs
}

\author{
Thesa Adi Purwanto* \\ Tax Administration Laboratory, Vocational Education Program, \\ Universitas Indonesia \\ *Emai: thesa@vokasi.ui.ac.id
}

\begin{abstract}
Internationalization of small and medium-sized enterprises (SMEs) has garnered much academic attention in terms of reasons and methods. Most of the studies adopt one of the three commonly used approaches: economic, network, and organizational. Each approach illustrates one's viewpoint but does not provide a comprehensive overview of SMEs' internationalization. The present study combines these three approaches by creating a structured framework theory. A qualitative approach with extensive content analysis is adopted. For this purpose, data were gathered from journals and other sources of literature. The study results show that the rapidly evolving concept of digital technology now appears to be a unifying factor in the integration of these three approaches. This concept can provide explanations not only about the "why," but also about "how" SMEs internationalize.
\end{abstract}

Keywords: internationalization of SMEs, digital technology, theoretical framework

\section{Introduction}

Globally, SMEs participate actively in the world economy. They represent $95-99 \%$ of the companies in the world according to the data of the Organization for the Economic Cooperation and Development (OECD, 2007), which is an international organization that helps governments address the economic, social, and governance challenges of the global economy. The member countries of the organization meet to compare their experiences of implementing policies, solving common problems, identifying good policy practices, and coordinating in the implementation of national and international policies.

Globally, SMEs are being encouraged to further develop and internationalize. Moreover, SMEs have become the subject of research. Currently, research on SMEs focuses on the reasons and the methods in which SMEs are moving toward internationalization (Ruzzier, Hisrich, \& Atoncic, 2006). There are several studies that deal with the concept of internationalization on SMEs. Most of the studies focus on one of the three commonly used approaches: economic, network, and organizational. Laghzaoui proposed new formulations by adding resource factors and skills to the three methods used by previous researchers (Soulaimane, 2011). The wording is intended to address the need for a common framework to integrate all research contributions using these three approaches. The process of internationalization of SMEs can be adequately explained if a combination of these three approaches is used (Leonidou, Katsikeas, \& Samiee, 2002).

However, the wording proposed by Laghzaoui should be updated, given the development of digital technology today. The present-day advanced digital technology, including fast and inexpensive access to information, opens up a vast opportunity for SMEs to innovate further (Redoli, Mompo, \& García-Díez, LopezCoronado, 2008). Rapid digitization and Internet access are the primary drivers of the SME strategy to address various operational issues (Noori \& Lee, 2006). In developed and developing economies, SMEs are driven by innovation, with multiple applications of information technology in various fields (Wu, Wang, Piperopoulos, \& Zhou, 2016).

The present study discusses the contribution of these three approaches. The objectives are twofold: (1) to examine the three methods to explain the process of internationalization of SMEs and (2) to reformulate the contribution of the three existing approaches by considering the aspects of the current development of digital technology. The concept of digital technology has not been developed specifically for SMEs. However, the idea of digital technology can be used as an analytical tool and adapted to reformulate the contributions of the three approaches. In reformulating this guide, it should provide a better understanding of the process of internationalization of SMEs.

\section{Methodology}

This research epistemology uses an interpretative paradigm to examine and solve a problem that highlights the socially constructed nature of reality. Guba explained that in the context of research design, selection of a 
research paradigm would guide the entire research process (Guba, 1990). The research paradigms determine the problem addressed and explain what can be accepted (Kuhn, 1970). Lincoln and Guba identify four main paradigms: positivism, post-positivism, constructivism, and critical theory. Sarantakos believes there are three dominant paradigms in the social sciences: the positivist, the interpretive and the critical (1998). Similar to Sarantakos, Neuman distinguishes the model of research in three paradigms: positivism, interpretation, and critique (2013).

The present study adopts the qualitative approach. Cresswell defines a qualitative study as "a process of understanding a social or human problem based on the construction of a complex and holistic image, formed with words, reporting detailed views of informants and carried out in a natural setting" (Cresswell, 2013). With regards to the qualitative approach, Neuman states that, "Data for qualitative researchers sometimes takes the form of numbers, more often written or spoken words, actions, sounds, symbols, physical objects or visual images. (e.g., maps, photographs, videos.)" (2013).

The study adopts a descriptive type of research. The descriptive study can be interpreted with problemsolving procedures studied by describing the state of the subject or object of the study at present based on facts that appear or as they are (Soejono \& Abdurrahman, 2005). Data collection techniques aim to collect data or information that can explain the problem of objective research. The present study collected and studied data and information obtained from journals, and other sources of literature. Content analysis and discourse analysis, which mainly rely on the models, structures, and language used in the written word, can be used when qualitative data has been collected. Content analysis is a procedure for categorizing behavioral data for classification, synthesis, and tabulation purposes. The content can be analyzed at two levels: (1) the basic or manifest level: a descriptive account of the data, that is, what has been said, but no comments or theories as to why or how; and (2) higher level or latent level of analysis: a more interpretative analysis concerning the answer as well as what may have been inferred or implied.

\section{Discussion and Results}

Early studies on international business development do not specifically target SMEs. Ruzzier summarizes some of the principles generated by the economic approach as follows:

- The theory of internalization, which states that companies can expand their business internationally by vertically merging (Buckley \& Casson, 1995).

- Transaction cost theory, which states that, in general, internationalization is the result of the choice of the enterprise between the internalization process and the external activity. This theory is a development of the method of internalization ( Willamson, 1975).

- An eclectic view (OLI) that bases its perspective on the theory of internalization. According to this view, internationalization can be seen from three following types of benefits owned by the firm (Dunning, 1988):

- The exclusive benefits, which are different for each company and relate to the ownership of intangible assets, for example, are technological and experiential capabilities;

- Geographical superiority, which refers to the location of the enterprise and factors of production in a geographic area;

- The benefits of internalization, achieved through the company's ability to organize and coordinate its internal activities.

The weakness of the economic approach is the difficulty of applying this method to analyze the process of internationalization of SMEs because, in principle, this approach is used for large companies. Therefore, the idea of using an organizational method states that the process of internationalization is a linear and sequential process composed of several stages (Coviello \& McAuley, 1999).. Researchers further categorized the two models used in this approach: Uppsala model and innovation model (Model I).

In the Uppsala model, the internationalization process is considered as a gradual process of learning. Continuous experience is considered a key to the process of internationalization (Johanson \& Vahlne, 1977). By combining the knowledge gained from experience in foreign markets, the company enhances the decisionmaking process. Internationalization is the result of this decision. Psychological distance is also a principle considered in this model. Psychological distances are cultural and linguistic differences that can influence the flow of information and decision making on international transactions.

In model I, internationalization is a gradual process, especially in the last product launch. Several studies have adopted this model to examine the process of internationalization in SMEs. Consequently, most researchers view each stage as the result of the company's innovation ( $\mathrm{Li}, \mathrm{Li}, \&$ Dalgic, 2004). The difference lies in the number of initial stages and the mechanisms of the internationalization process in SMEs. Moreover, Leonidou summarizes the variation of the steps arising from the use of this three-step model (Leonidou \& Katsikeas, 1996) as follows: 
- $\quad$ Pretreatment stage: the company focuses exclusively on the national market; the company intends to export; the company shipped but did not continue its export activities.

- The initial stage of the process: the company exports in an irregular manner, whereas it has the potential to develop abroad.

- Next step in the process: the company exports regularly to gain experience overseas; companies are considering internationalization.

Because this approach involves several stepwise variations, the study results are debatable mainly when used to examine the process of internationalization of SMEs. Therefore, the network approach is needed (Westhead, Ucbasaran, \& Biks, 2004).

The networking approach is developed from the modified Uppsala model, emphasizing the importance of the company's position on its network. Therefore, the process of internationalization can be defined as the result of relationships built through commercial activities in other countries through three stages (Johanson \& Mattson, 1988), that is, extension, penetration, and integration. Prolongation is the first step in network integration. This stage is marked by the entry of new investments in the company. The penetration phase begins with the changing position of the company in its network and the increased commitment. Integration is the advanced stage where the company is already connected and must coordinate with several networks in other countries.

Therefore, according to this approach, internationalization is a cumulative process in which a relationship is created, developed, and maintained continuously to achieve the objectives of the enterprise. A company is considered to have undergone the process of internationalization if other companies in the network are international companies. In this approach, continuous learning and knowledge extraction through interaction within the network is paramount (Johanson \& Mattson, 1988). The network approach offers another perspective in interpreting the process of internationalization of SMEs. The availability of networks is essential for SMEs to augment their limited resources.

Several approaches analyze the process of internationalization of SMEs; however there is a need for a common framework to explain the process (Hutchinson, Alexander, \& Quinn, 2005). The framework should complement the existing approaches and match the different characteristics of SMEs. Therefore, the development of digital technology is proposed as a unifying concept in an existing approach. The purpose of the present study is not to replace the methods that have been used in the analysis of the process of internationalization of SMEs but to develop and complement the development of the current era. Moreover, internationalization of SMEs is a complicated and heterogeneous process (Bourcieu, Salgado, \& Thivin, 2006), which needs integration of all approaches for a comprehensive analysis.

By combining all the approaches in analyzing the process of internationalization of SMEs, some factors such as financial, resources, and networks are identified that lead to differences in each context of different SMEs. The concept of digital technology development is currently the most relevant concept to serve as a unifying concept and become an essential part of the process of internationalization of SMEs, both internally and externally (Krasnikov \& Jayachandran, 2008). International entrepreneurial orientation and competition in the domestic market has prompted SMEs to develop its technological and marketing capabilities, which has improved performance in international markets. The full media effects of technological and marketing skills were found between international entrepreneurial orientation and export performance (Jin \& Cho, 2018).

Several studies have highlighted the effect of technological variables on the export performance of SMEs, including innovation (Azar \& Ciabuschi, 2017), learning (Zhou, Wu, \& Luo, 2007), and competence (Knight \& Cavusgil, 2004). For example, technological innovation improves export performance (Azar \& Ciabuschi, 2017). Acquiring knowledge of advanced and new technologies from foreign countries is also significantly correlated with export performance (Zhou, Wu, \& Luo, 2007). Investment in technology development can reduce manufacturing costs and help differentiate products and services from competition through innovative designs and functions (Kotabe, Srinivasan, \& Aulakh, 2002).

Digital technologies such as the Internet of Things (IoT), big data, simulation approaches based on highperformance computing applied to manufacturing processes (where they were renamed "Industry 4.0" or intelligent manufacturing) and services have increased the dynamism and complexity of the market and the technological environment of SMEs (Schröder, 2017). These technologies have also led to the emergence of new market mechanisms such as economic sharing and servitization, which are intensifying competitive pressures, altering market equilibria, and changing the structure of the industry. These changes translate to increased dynamism and complexity for SMEs in sectors such as retail, hospitality, industrial machinery, and textiles (Neirotti, Raguseo, \& Paolucci, 2018).

In general, companies can develop two types of meta-capabilities from digital technology: "inward oriented" (IO) or "outward oriented" (EO) (Dale Stoel \& Muhanna, 2009). IO capabilities are based on the use of digital technology systems, such as Enterprise Resource Planning (ERP) solutions, to process information about internal business operations. These systems can help managers in making operational decisions related to short-term horizons, which can help in improving efficiency and controlling operations by integrating data across functions (Wade \& Hulland, 2004). EO capabilities rely on the use of digital technology to support 
business model innovation, new product development activities, e-commerce initiatives, and customer relationship management processes (CRM). EO capabilities therefore reflect the ability to use digital technology to detect and process external market information. Firms having IO and EO capabilities should, therefore, be better able to reconfigure their products, business models, and supply chain relationships (Borges, Hoppen, \& Bins Luce, 2009). In particular, CRM systems that aim to support efforts toward generating market intelligence and digital technology systems supporting SMEs are crucial for market responsiveness and coordination with partners-market in product innovation. As EO capabilities can also include the ability to execute e-commerce initiatives, they can allow the cost of entry into new market segments.

Moreover, digital technology plays a significant role before and during the process of internationalization of SMEs. Before the internationalization process is decided, digital technology influences trends and engagement in the process. Digital technology serves as an internal factor influencing internationalization decisions, which also affects the pace and intensity of the process.

\section{Conclusion}

This conceptual theory can be used to describe the process of internationalization of SMEs considered complicated. The complexity of the process can be explained by various approaches, such as economic approach, organizational approach, and network. Each provides consistent viewpoint but cannot afford a comprehensive overview of the process of internationalization of SMEs. This study aims to combine these three approaches by creating a structured framework theory. The rapidly evolving concept of digital technology now seems to be a unifying factor in the integration of these three approaches. This concept can provide explanations not only about the why,"' but also about "how" SMEs undertake the process of internationalization.

From the theoretical perspective, this study contributes to understanding the process of internationalization of SMEs through the concept of digital technology. This concept combines all the existing approaches to illustrate the diversity of the process's For policymakers, in order to understand how and why SMEs experience the internationalization process, it is planned to create a national program for active international promotion and international marketing. For practitioners, this study on the internationalization of SMEs can serve as a guide for applying the approaches that have been adopted in the process of internationalization of SMEs. The results of this study have put digital technology at the heart of the analysis of SMEs. The concept can capture the essential characteristics of SMEs in the development of the current era.

\section{References}

Azar, G., \& Ciabuschi, F. (2017). Organizational innovation, technological innovation, and export performance: The effects of innovation radicalness and extensiveness. International Business Review, 26, 324-36.

Borges, M., Hoppen, N., \& Bins Luce, F. (2009). Information technology impact on market orientation in ebusiness. Journal of Business Research, 62(9), 883-890.

Bourcieu, S., Salgado M., \& Thivin S. (2006). Dynamique d'internationalisation des PME Rhone-Alpes, in Actes du 8ème CIFEPME, Suisse.

Buckley, P. J., \& Casson, M. The economic theory of multinational enterprise. (1995). New York, NY: StMartin's Press.

Coviello, N. E., \& McAuley, A. (1999). Internationalization and the small firm: A review of contemporary empirical research. Management International Review, 39(3), 223-237.

Cresswell, J. W. (2013). Research design: Qualitative, quantitative and mixed methods approaches. London: Sage Publication Inc.

Dale Stoel, M., \& Muhanna, W.A. (2009). ICT capabilities and firm performance: A contingency analysis of the role of industry and ICT capability type. Information and Management, 46, 181-189.

Dunning, J. H. (1988). The eclectic paradigm of international production: A restatement and some possible extension. Journal of Small Business Studies, 19, 1-31.

Guba, E. G. (Ed.). (1990). The paradigm dialog. Newbury Park, CA: Sage.

Hutchinson, K., Alexander, N., \& Quinn, B. (2005). The internationalization of small to medium-sized retail firms: towards a conceptual framework. Journal of Marketing Management, 21(1-2), 149-179.

Jin, B., Cho, H. J. (2018). Examining the role of international entrepreneurial orientation, domestic market competition, and technological and marketing capabilities on SME's export performance. Journal of Business \& Industrial Marketing. 
Johanson, J., \& Mattson, L.-G. (1988). Internationalization in industrial systems-A network approach. In N. Hood \& J.-E. Vahlne (Eds.), Strategies in global competition (pp. 287-314). New York: Croom Helm.

Johanson, J., \& Vahlne, J.E. (1977). The internationalization process of the firm: A model knowledge development and increasing foreign market commitments. Journal of International Business Studies, 8, 332.

Knight, G.A., \& Cavusgil, S.T. (2004). Innovation, organization capabilities, and the born-global firm. Journal of International Business Studies, 35(2), 124-141.

Kotabe, M., Srinivasan, S., \& Aulakh, P. (2002). Multinationality and firm performance: The moderating role of R\&D and marketing capabilities. Journal of International Business Studies, 33, 79-97.

Krasnikov, A., \& Jayachandran, S. (2008). The relative impact of marketing, research and development, and operations capabilities on firm performance. Journal of Marketing, 72(4), 1-11.

Kuhn, T. S. (1970). The structure of scientific revolutions $\left(2^{\text {nd }}\right.$ ed). Chicago, IL: University of Chicago Press.

Leonidou, L.C., \& Katsikeas, C.S. (1996). The export development process: An integrative review of empirical models. Journal of International Business Studies, 27, 517-551.

Leonidou, L.C., Katsikeas, C.S., \& Samiee, S. (2002). Marketing strategy determinants of export performance: A meta-analysis. Journal of Business Research, 55, 51-67.

Li, L., Li, D., \& Dalgic, T. (2004). Internationalization process of small and medium-sized enterprises: Towards a hybrid model of experiential learning and planning. Management International Review, 44, 93-116.

Neirotti, P., Raguseo, E., \& Paolucci E. (2018). How SMEs develop ICT-based capabilities in response to their environment: Past evidence and implications for the uptake of the new ICT paradigm. Journal of Enterprise Information Management, 31, 10-37.

Neuman, W. L. (2013). Social research methods, qualitative and quantitative approaches, $\left(7^{\text {th }}\right.$ Ed). New York, NY: Pearson Higher Education.

Noori, H., \& Lee, W.B. (2006). Dispersed network manufacturing: Adapting SMEs to compete on the global scale. Journal of Manufacturing Technology Management, 17, 1022-1041.

OECD. (2007). Le financement des PME et des entrepreuneurs. Synthèses, Février. http://www.eurosfaire.prd.fr/7pc/doc/1202808615_fiche_pme_ocde_2007.pdf

Redoli, J., Mompo, R., García-Díez, J., \& López-Coronado, M. (2008). A model for the assessment and development of Internet-based information and communication services in small and medium enterprises. Technovation, 28(7), 424-435.

Ruzzier, M. R., Hisrich, D., \& Atoncic, B. (2006). SME internationalization research: Past, present and future. Journal of Small Business Enterprise Development, 13, 476-497.

Sarantakos, S. Social Research ( $2^{\text {nd }}$ Ed). (1998). China: Macmillan Publishers.

Schröder, C. (2017). The challenges of industry 4.0 for small and medium-sized enterprises. Germany: Friedrich-Ebert-Stiftung.

Soejono, H., \& Abdurrahman, H. (2005). Metode penelitian: Suatu pemikiran dan penerapan. Jakarta: Rineka Cipta.

Soulaimane, L. (2011). SMEs' internationalization: An analysis with the concept of resources and competencies. Journal of Innovation Economics \& Management, 7, 181-196.

Wade, M., \& Hulland, J. (2004). The resource-based view and information systems research: review, extension, and suggestions for future research. MIS Quarterly, 28, 107-142.

Westhead, P., Ucbasaran, D., \& Biks, M. (2004). Internationalization strategies selected by established rural and urban SMSs. Journal of Small Business and Entrepreneurship Development, 11, 8-22.

Willamson, O. (1975). Markets and Hierarchies. New York, NY: Free Press.

Wu, J., Wang, C., Piperopoulos, P., \& Zhou, B. (2016). Internationalization and innovation performance of emerging market enterprises: The role of host-country institutional development. Journal of World Business, 51, 251-263.

Zhou, L., Wu, W.P., \& Luo, X. (2007). Internationalization and the performance of born global SMEs: The mediating role of social networks. Journal of International Business Studies, 38, 673-690. 